\title{
ANALISIS TITIK IMPAS UNTUK MENENTUKAN HARGA POKOK PENJUALAN RUMAH DI MAKASAR
}

\author{
Retna Kristiana ${ }^{1}$, Abdul Hamid ${ }^{2}$ \\ ${ }^{1}$ Jurusan Teknik Sipil, Universitas Mercu Buana \\ Email:kristianaretna@mercubuana.ac.id
}

\begin{abstract}
ABSTRAK
GVM Makassar adalah perumahan yang di kembangkan oleh PT. SA yang berasal dari Jakarta. GVM Makassar mengembangkan dua tipe rumah S6 dan S7 yang mana tipe ini telah meraih sukses di Jakarta dan Karawang. Karena di Makassar adalah lokasi baru bagi PT. SA maka peneliti mencoba membantu perusahaan untuk menentukan penetapan harga jual rumah type S6 dan S7 agar dapat meraih pangsa pasar. Metode yang digunakan dalam penelitian ini adalah merencanakan biaya dengan menganalisis perbandingan material antara Makassar dan Jabodetabek kemudian membuat Value Engineering. Dari hasil Value Engineering nanti dibuat total perencanaan biaya kemudian mencoba membandingkan, menganalisis antar beberapa kompetitor yang berada di Makassar. Setelah melakukan analisis harga satuan yang didapatkan dari hasil survei harga material di Makassar dan Jabodetabek yang kemudian di Value Engineering untuk mendapatkan harga pokok produksi dilanjutkan dengan menentukan harga pokok penjualan dan margin keuntungan harga aktual rumah tipe S6 dan S7 yang telah dilakukan dengan analisis titik impas total unit terjual oleh developer yang mengembangkan di Makassar sebelumnya, maka harga pokok penjualan terhadap margin profit yang ditetapkan pada rumah tipe S6 Rp. 707.084.005 margin keuntungan sebesar 33,8 \% dengan 96 unit penjualan, sedangkan untuk rumah tipe S7 Rp. 906.880.750 margin keuntungan sebesar 45,30\% dengan 104 unit penjualan.
\end{abstract}

Kata kunci: material, value engineering, titik impas, harga pokok, rumah

\section{PENDAHULUAN \\ Latar Belakang}

Sulawesi Selatan dikarunia potensi sumberdaya yang berlimpah, terutama sumberdaya manusia dan sumberdaya alam antara lain pasir besi, batu gamping, marmer, pasir kuarsa dan lain-lain. Besarnya potensi tersebut merupakan modal yang sangat berharga bagi daerah ini dalam melaksanakan aktivitas pembangunan.

Sektor properti menjadi salah satu cerminan kemajuan pertumbuhan sebuah kota, maka tidak berlebihan apabila belakangan ini hitungan angka pertumbuhan ekonomi di kota Makassar selalu bergerak melebihi angka pertubuhan rata-rata nasional. Denyut sektor usaha properti di kota Makassar dalam kurun lima tahun terakhir terasa kencang salah satunya adalah perumahan $G V M$ Makassar.

GVM Makassar adalah perumahan yang di kembangkan oleh PT. SA yang berasal dari Jakarta. PT. SA pertama kalinya mencoba untuk mengembangkan properti di daerah Makassar. PT. SA tersebut mencoba untuk mengembangkan di daerah Makassar dengan berbagai tantangan antara lain lokasi baru yang sama sekali belum pernah tahu pangsa pasarnya, kualitas seperti apa yang diminati masyarakat, seberapa besar harga jual yang sesuai dengan kantong masyarakat dan beberapa tantangan lainnya. Dalam pengembangan di lokasi baru ini PT. SA tetap mencoba untuk mengembangan dengan konsep, dan kualitas yang selama ini telah di lakukan di Jabodetabek dan menjadikan suksesnya perusahaan. Akan tetapi karena ini adalah pengembangan lokasi baru yang perusahaan belum tahu pangsa pasarnya perusahaan tetap memperhatikan kompetitor yang kurang lebih masih satu level dengan PT. SA yang ada di Makassar. 
Perbedaan lokasi pembangunan sangatlah berpengaruh pada nilai total perencanaan biaya bangunan terutama Makassar dengan Jabodetabek. Makassar memang cukup terkenal dengan kekayaan alamnya akan tetapi untuk material finishing seperti alumunium, jenis-jenis keramik dan lain sebagainya masih cukup minim dan harus mendatangkan dari luar Makassar sedangkan Jabodetabek adalah pusat kota di mana pengembangan properti sangatlah ramai yang menjadikan hal tersebut semua material bangunan mudah didapat dengan harga yang bersaing. Dengan adanya perbedaan tersebut penulis mencoba untuk merencanakan biaya dengan menganalisis perbandingan material antara Makassar dan Jabodetabek kemudian membuat Value Engineering. Penulis dalam penelitian ini akan menggunakan Value Engineering untuk mencoba membantu PT. SA agar dapat mendapatkan perencanaan anggaran biaya yang optimal sehingga perusahaan dapat menetapkan harga pokok penjualan rumah dalam pengembangan barunya di Makassar.

Dengan adanya pengembangan baru di Makassar perusahaan dengan ini mencoba mengembangkan rumah type S6 dan S7 dimana tipe tersebut pada penjualan tahun 2016, 2017 telah sukses meraih pasar di Serpong dan Karawang dengan kualitas dan spesifikasi yang sesuai standar PT. SA.

\section{Rumusan Masalah}

1. Seberapa besar perbedaan total nilai biaya pembangunan rumah tipe S6 dan S7 dengan menggunakan desain, spesifikasi dan metode yang sama jika menggunakan material Makassar dan Jabodetabek?

2. Berapa besar total nilai biaya pembangunan rumah tipe S6 dan S7 setelah value engineering pada spesifikasi yang masih dalam lingkup standart PT. SA?

3. Berapa nilai total harga penjualan rumah tipe S6 dan S7 setelah di tambah dengan biayabiaya infrastruktur lainnya?

4. Dapatkah PT. SA menarik konsumen dengan penetapan harga jual dari nilai total biaya pembangunan dengan ditambah biaya-biaya lainnya pada pengembangan lokasi di Makassar?

\section{METODE PENELITIAN}

Dalam menetapkan harga, penelitian ini menggunakan metode analisis titik impas, yang mempertemukan antara kurva biaya dan kurva permintaan menggunakan persamaan $\mathrm{MC}=\mathrm{MR}$ untuk mencari $\mathrm{Q}$ optimum (volume optimum). MR (marginal revenue) adalah perubahan pendapatan untuk perubahan satu unit yang terjual, merupakan turunan dari TR (Total Revenue). TR merupakan perkalian dari persamaan harga jual dengan jumlah unit terjual. MC (marginal cost) adalah perubahan biaya yang disebabkan perubahan satu unit rumah yang terjual, merupakan turunan dari TC (Total Cost). TC adalah total biaya yang dibutuhkan untuk membuat seluruh unit rumah. (Gaspersz, 2001)

Langkah-langkah perhitungan meliputi :

a. $\mathrm{P}=\mathrm{f}(\mathrm{q})$ Persamaan harga jual yang diperoleh dari kurva permintaan berdasarkan hasil survey terhadap responden.

b. $\mathrm{TR}=\mathrm{P} \times \mathrm{Q}$ Total revenue adalah total pendapatan yang diperoleh dari hasil perkalian antara persamaan harga jual $(\mathrm{P})$ dan $\mathrm{Q}$.

c. $\mathrm{MR}=\Delta \mathrm{TR} / \Delta \mathrm{Q}$, Marginal revenue adalah perubahan pendapatan untuk perubahan satu unit yang terjual, merupakan hasil dari turunan TR.

d. $\mathrm{TC}=\mathrm{FC}+\mathrm{VC}(\mathrm{Q})$ Total cost adalah total biaya yang dibutuhkan untuk membuat seluruh unit rumah. 
e. $\mathrm{MC}=\Delta \mathrm{TC} / \Delta \mathrm{Q}$ Marginal cost adalah perubahan biaya yang disebabkan oleh perubahan satu unit rumah yang terjual, merupakan hasil dari turunan TC.

f. $M C=M R$ Laba atau keuntungan tercapai pada saat kondisi $\mathrm{MC}=\mathrm{MR}$, perhitungan dilakukan untuk mendapatkan Q yang optimal. Setelah mendapatkan Q, maka Q dimasukkan ke dalam persamaan harga jual yang diperoleh untuk mendapatkan harga jual rumah yang sesuai.

g. Setelah semua harga didapatkan kemudian melakukan perbandingan antar developer dengan hasil survei penjualan developer lain di Makassar yang sama.

\section{HASIL DAN PEMBAHASAN}

\section{Rekapitulasi Biaya Tetap}

Rekapitulasi biaya tetap adalah total biaya dari berbagai biaya tetap yang nantinya digunakan untuk harga penjualan tanah pada penjualan rumah tipe S6 dan S7 sebagai berikut:

1. Total biaya Infrastruktur cluster jika dibebankan ke dalam penjualan adalah Total Harga Infrastruktur / Luas lahan Efektif. Biaya infrastruktur cluster adalah sebesar 28.063.237.170 / $25.530=$ Rp. $1.099 .226 / \mathrm{m} 2$.

2. Total biaya infra utama kawasan di atas adalah total seluruh biaya pekerjaan yang akan di beban pada setiap lahan efektif. Beban biaya infra utama = Total biaya infra utama/luas lahan efektif. Rp. 802.546.557.764/1.353.110 = Rp. 593.113 / m2

3. Total pembebasan lahan dalam pengembangan ini adalah Rp. 800.000/m2 dengan luas lahan 2.242.696 menghabiskan uang sebesar Rp. 1.794.156.800.000.

4. Total biaya operasional adalah sebesar Rp. 5.400.000.000/tahun. Jika di bagi dengan luas lahan efektif cluster yaitu sebesar 5.400.000.000 / $25.530 \mathrm{~m} 2=\mathrm{Rp} .211 .516 / \mathrm{m} 2$

5. Total biaya yang dibutuhkan dalam setahun untuk pemasaran adalah Rp. 7.500.000.000 jika dibagi dengan luas lahan efektif adalah Rp. 7.500.000.000 / 25.530 m2 = Rp. 293.722/m2

\section{Perhitungan Harga Pokok Produksi}

Harga pokok produksi dapat dihitung dengan menggunakan persamaan berikut :

$\mathrm{S}=\mathrm{VC}+\mathrm{FC} / \mathrm{Q}$

Di mana: $\mathrm{S}=$ Harga pokok penjualan rumah

$$
\begin{aligned}
& \mathrm{FC}=\text { Biaya tetap } \\
& \mathrm{VC}=\text { Biaya Variabel } \\
& \mathrm{Q}=\text { Jumlah unit rumah }
\end{aligned}
$$

Sehingga didapatkan harga pokok produksi per unit rumah tipe S6 dan S7 sebagai berikut

\begin{tabular}{|c|c|c|c|c|}
\hline No. & Tipe Rumah & FC ( Rp) & VC ( Rp) Q ( Unit ) & $\mathrm{S}(\mathrm{VC}+\mathrm{FC} / \mathrm{Q})(\mathrm{Rp})$ \\
\hline 1 & S7 & 28.687 .290 .390 & 47.939.900.000 & 528.463 .382 \\
\hline 2 & S6 & 47.842 .126 .920 & 70.745 .170 .000 & 624.143 .668 \\
\hline
\end{tabular}
tercantum dalam tabel 1 :

Tabel 1 Harga Pokok Produksi

Dari hasil perhitungan analisis harga satuan yang didapatkan dari hasil survei harga material di Makassar dan Jabodetabek yang kemudian di Value Engineering untuk mendapatkan harga pokok produksi dilanjutkan dengan menentukan harga pokok penjualan dan margin keuntungan harga aktual rumah tipe S6 dan S7 yang telah dilakukan dengan analisis titik impas total unit 
terjual oleh developer yang mengembangkan di makassar sebelumnya, maka dapat dibuat tabel dan kurva harga pokok penjualan terhadap margin profit yang ditetapkan pada setiap tipe rumah. Harga pokok penjualan rumah tipe S6 dengan jumlah unit rumah maksimum 145 unit. Dalam penentuan margin profit dengan penjualan maksimum dan bep tercantum dalam tabel 2 sebagai berikut.

Tabel 2. Harga Rumah

\begin{tabular}{lcccc} 
No. & Tipe Rumah & Harga Pokok Produksi (Rp.) & Margin Profit (\% ) & Harga Pokok Penjualan ( Rp. ) \\
\hline 1 & S6 & 528.460 .382 & 33,8 & 707.084 .005 \\
\hline 2 & S7 & 624.143 .668 & 45,3 & 906.880 .750 \\
\hline
\end{tabular}

\section{KESIMPULAN DAN SARAN}

\section{Kesimpulan}

Berdasarkan hasil analisis dalam penelitian ini dapat disimpulkan bahwa:

1. Perbedaan harga antara Makassar dengan Jabodetabek untuk rumah tipe S6 sebesar 6,77\% yaitu: Harga Makassar sebesar Rp. 382.609.700 Included Ppn 10\% sedangkan harga Jabodetabek sebesar Rp. 356.672.900 Included Ppn10\%. Untuk rumah tipe S7 sebesar 6,51 \% yaitu : Harga Makassar sebesar Rp. 432.206.500 Included Ppn 10\% sedangkan harga Jabodetabek sebesar Rp. 404.044.300 Included Ppn $10 \%$.

2. Setelah melakukan Value Engineering harga rumah tipe S6 menjadi Rp. 363.682 .000 Included Ppn 10\% lebih efisien 4,95 \% dari harga Makassar yang sebelumnya. Sedangakan untuk rumah tipe S7 menjadi Rp. 409.577.300 Included Ppn 10\% lebih efisien 5,23\% dari harga Makassar yang sebelumnya.

3. Dari hasil Value Engineering kemudian ditambah dengan alokasi biaya lain-lain seperti biaya infrastruktur, biaya tanah dan biaya lain-lainya, total harga pokok produksi menjadi Rp. 528.460.382 untuk rumah tipe S6, sedangkan untuk rumah tipe S7 menjadi Rp. 624.143.668. Dari hasil perhitungan harga pokok produksi kemudian ditambah dengan margin keuntungan total harga penjualan menjadi Rp. 707.084.005 Excluded Ppn 10\% untuk rumah tipe S6, sedangkan untuk rumah tipe S7 menjadi Rp. 906.880.750 Excluded Ppn 10\%.

4. Jika dibandingkan dengan harga kompetitor yang berada di Makassar harga yang didapat dalam penelitian masih masuk dalam harga pasar yaitu harga rumah tipe S6 yang paling banyak terjual oleh pengembang TB BSA land sebesar Rp. 1.470.000.000 sedangkan harga hasil penelitian sebasar Rp. 707.084.005. untuk harga rumah tipe S7 yang paling banyak terjual oleh pengembang RS 2 CP sebesar Rp. 927.500 .000 sedangkan harga hasil penelitian sebesar Rp. 906.880.750.

\section{Saran}

Berdasarkan proses analisis pada penelitian ini, saran yang dapat diberikan untuk penelitian lebih lanjut adalah:

1. Untuk analisis harga satuan lebih memperdalam harga material yang berada di Makassar karena dalam penelitian ini, peneliti hanya melakukan 6 kali survei harga dan suvei kompetitor di Makassar.

2. Diharapkan pada penelitian selanjutnya untuk lebih memperdalam upah pekerjaan di Makassar, mengamati sistem kerja tenaga kerja di Makassar.

3. Untuk penelitian selanjutnya agar memperhitungkan juga inflasi harga material. 


\section{Ucapan Terima Kasih}

Penulis mengucapkan terima kasih kepada para partisipan penelitian ini, khususnya PT. SA yang telah menyediakan data yang diperlukan.

\section{REFERENSI}

Alfian, B. (2014). Analisa Penetapan Harga Jual Unit Rumah Pada Pengembangan Perumahan Grand Mandiri Residence, Depok. Jakarta.

Donny, R. (2016). Analisis Selisih Biaya Pembangunan Proyek Konstruksi Pada PT. Tastia Permata Sejahtera di Samarinda. Kalimantan.

Eskandar, H. (2016). Optimalisasi Biaya dan Analisis Sensitivitas Balok Komposit. Jakarta

Fharel, N. (2014). Perencanaan Biaya dengan menggunakan Perhitungan Biaya Nyata pada Proyek Perumahan (Studi Kasus Perumahan Green Hill Residence). Jakarta

Hermansyah, D. (2014). Estimasi Anggaran Biaya Kosntruksi \& Rencana penjadwalan Tahap Desain Pada Proyek Pembangunan Kampus BSI Margonda, Depok. Jakarta

Nitha, D. (2015). Analisis anggaran \& Realisasi Biaya Proyek pembanguna kantor Dinas pada CV. Banyu Bening di Samarinda, Kalimantan.

Puti, D. (2014). Analisis Pembiayan Pembangunan Perumahan Puri Cempaka Mas Dalung Kuta Utara Kab. Badung, Bandung.

Sugiyono. (2016). Stastistika untuk Penelitian. Bandung: Alfabeta.

Utomo, T. (2014). Penetapan Harga Pokok Penjualan Berdasarkan alokasi Biaya terhadap Posisi Rumah Perumahan Green Park Residence Sampang Surabaya Serang Residence. Jakarta

Winoto D. Y. \& Agnes. (2014). Rencana Anggaran Biaya Untuk Rumah Sederhana. Yogyakarta: Macananjaya Cemerlang. 